\title{
2. DEVELOPMENT OF ARTISTIC CREATIVITY IN STUDENTS BY STUDYING AND APPLYING ORNAMENTAL MOTIVES IN THE TEXTILE ART COURSE
}

Olimpiada Arbuz-Spatari ${ }^{218}$

\begin{abstract}
In the training process within the textile art course, a system of methods of studying and applying the elements of the plastic language is used within the proposed methodology, which was followed by the development of artistic creativity in the students of the plastic art faculty. These methods were developed and applied in the course of textile art for the compartments: elaboration of creative compositions; consciously applying the elements of plastic language; studying and applying ornamental motifs in the textile art course. The methods developed for the textile art course, in their interaction, will contribute to the development of the student's artistic creativity, helping him to execute the creative product in the field of textile arts.
\end{abstract}

Key words: artistic creativity, ornamental motifs, textile art

\section{Introduction}

Ornamentation in general, and the popular (traditional and contemporary), in particular, includes three basic components: the item, the motif and ornamental composition.

- The ornamental element is the simplest (elementary) part of an ornament.

- The ornamental motif consists of two or more ornamental elements, making a whole decorative representation, visible in ornamental elements of the same thematic group: flower, star, tree, bird, man etc.

- The ornamental composition results from two or more ornamental motifs, without necessarily belonging to the same thematic group or to the same stylistic group.

The plastic language, besides its particularities of elaboration, implies the application of a codified system of signs. The plastic signs reflect the cultural codes specific to the genres of art. The definition of the concept of plastic signs refers to the presence and the specific meanings of the plastic elements that enter the process of elaborating the creative composition: from lines and points to silhouettes and volumes. The plastic signs are presented in figurative and nonfigurative compositions, and their reception depends on the amount of information contained [4, p. 122].

\section{Discussions}

Thus, in our time, artificial languages have become widely used as sign systems that fulfill a combined function of knowledge and communication. The

\footnotetext{
${ }^{218}$ Associate Professor PhD, "Ion Creanga" State Pedagogical University from Chişinău, Republic of Moldova, email: olimpiada123@mail.ru
} 
difficulty of sensitive penetration and rational decoding of the artistic language increases in direct relation with the evolution of art, from the classical-realistic presentation, to the abstract, modern presentation of the plastic image, from the figurative to the non-figurative, from a smaller quantity to a greater number of signs and, implicitly, from the semantic to the aesthetic information [6]. Therefore, the signification of the signs of plastic language poses certain creative problems to the creative personality, including:

1. knowledge of specific codes and sub-codes for different types of art, of different conventions adopted, of the differences between the creative styles;

2. understanding the unity relation between semantics and syntactic, with the particular mode of existence, information;

3. the recognition of the superiority of the syntactic to the semantic in all the basic planes of the artistic representations: in the plane of the composition of the meaning, of the expressiveness, originality, etc .;

4. admitting cognitive subtlety that shows that the world, things are unfolding in front of us in a dialectical and semantic-syntactic way.

The semantics is in unity with the syntactic, in the sense of framing the plastic-shaped components, which represent the semantic sphere, in geometric figures, in canons, proportions - the latter constituting the syntactic structure. The points merge into lines, shapes. Lines integrate with colors, volumes, symmetry or asymmetry, etc. All together they are incorporated - and there are plenty of them - on different levels, with a creative vision with its syntactic constituent. Another way, in plastic creation, meant to develop creativity in students and illustrating semantics and syntactic, is given by the application of plastic elements of language, according to certain compositional principles, according to certain rules, among which the more known are: symmetry, asymmetry, alternation, respecting some proportions [7, p. 41-44]. Compared with the denotative "signs of science", with their universal meaning for all who know the code, the semantics of art are characterized by connotation [Ibidem, p.38].

The signs of fine art are characterized by connotation (as opposed to the signs of science with their denotative meaning, with their universal significance for all who know the code), the diversity and difficulty of knowing the sub-codes of art. The connotative character of the signs of the plastic art manifests itself with differences from the semantic and syntactic perspectives. The semantics of the fine art comprises simple elements, with their singular, incipient and non-unitary meaning, with meanings in which certain degrees of knowledge of the unknown elements are present, with notes of resemblance and partial equivalence to nature (for example: lines, colors, shapes, movements-rhythms, volumes of different sizes etc.). The syntactic is characterized by a clustering, a clustering of several simple constituents, such as those listed above and, consequently, by the perception of the whole in which the semantic notes are incorporated. Art is expressed through metaphorical (connotative) language and, for this reason, manages to capture only part of the essence of reality, the other being "poetry". 
The abstractization of the plastic geometric form that has become a sign, meaning in the subjective system of creative reflection of the creative personality, becomes a symbol. Like any symbol, the geometric symbol has a conventional character. This conventionality can be determined either at the level of a culture, a current or artistic movements, or at the scale of an artist's creation. Due to the expressive complexity of the geometric meanings, the geometric symbol becomes an overlapping geometric language and is correlated with the plastic language. Symbols are the center of attention, they being the very essence of imaginative life, because they reveal the secrets of the unconscious, they move the most hidden springs of actions and offer new perspectives on the unknown and infinity. Studying the symbol is very important for the successful realization of any artistic creation in the field of textile art.

According to the specified meaning, the symbol represents a sign, object, phenomenon that is vested with a special capacity to convey ideas, concepts, even ideological allusions, much more complex than their simple representation, according to a generally accepted code. In the fine arts, the symbol is a visual sign with an allusive character, referring to a different material or spiritual reality, than the one that the image depicts. The symbol can be noticed and intuitive, in some cases, when the sign and what it signifies have both a concrete character. However, there are also repertoire symbols of ancient visual experiences, such as the color symbol, the numerical symbols [4, p.128]. The emotional consistency of a geometric form is perhaps justified by the author's imaginative matrix; geometrical figures and volumes, which do not actually exist in reality, being a product of human fantasy and intelligence. In this context, Zamfir Dumitrescu proposes three categories of symbolic interpretation of geometric figures and shapes:

- the category of geometric symbols with associative value; this category including the geometric figures adopted as a symbol for an idea, a historical, social, religious notion, through an association, removed from the structural-geometrical motivation of the sign that has become a symbol;

- the category of symbols with a purely conventional value within systems recognized and established as such, such as mathematical, logical, physical, chemical, etc .;

- the category of symbols in which they receive their structural-geometric value, with the respective implications on the level of visual perception and psychological effects in the representation of the geometric form [5, p. 34].

Out of this classification we can take notice of the fact that the third category of geometric symbols is in correlation with the elements of the plastic language. The geometric shapes overlap with the elements of the plastic language (square, rectangle, spiral, etc.). The conventional-geometric codes stipulate in the plane of the psychology of perception, the following ideal correspondences: the point - the idea of localization, marking (punctuation); the triangle - the idea of dynamism (a dynamism resulting from the force suggested vertically by the sharp 
tip of the angles, sometimes consecrated by the size and proportion of the closed figure); the square - the idea of stability due to the order within its area determined by the four right angles and the equality of the sides [3, p. 382].

The geometric symbols also apply to the elaboration of plastic compositions in textile art, which make use of the visual image of the geometric symbol. The geometric sign appears frequently in simple, non-coded languages, or with an easily accessible number, without previous specialized training. Analyzing the principles of applying geometric symbols and forms in the elaboration of decorative compositions, it is obvious the process of transforming the geometric symbol into a plastic symbol, having as its purpose the synthesis (geometricalplastic) of the signs that have become, by creation, symbols. The geometric symbol, included in the third category, approaches until the total overlap with the plastic symbol. The few geometric-plastic forms (point, triangle, square, angles: right, sharp, obtuse), are the primary plastic geometric shapes analyzed in the present research, derived from the condition of the straight line. Along with the straight line, the study of the curved line, with its multiple hypostasis - open (spirals, parabola, hyperbola, etc.) and closed (plane figures of the circle, ellipse, oval etc.) - gives us structural-geometric stages with an expressive plastic content specific [3, p. 44]. Therefore, the geometric and plastic symbols contribute eloquently to the development of creativity in students, perpetuating, according to the researcher V. Vasilescu, "the genetic stock of people united by common beliefs and by the permanence of the signs that linked bridges over time" $[9, \mathrm{p}$. 72] .

\section{Results}

It should be mentioned that the study of decorative art, in general, and the study of traditional folk ornamentation, in particular, is an essential compartment in the course of textile art. The transformation of the elements of the plastic language into ornamental decorative motifs by methods of geometrization and abstraction and their application in the creative compositions of textile art are objectives that underlie the stimulation of the artistic creativity in the students of the faculties of fine arts. Folk art develops students' aspirations, experiences, taste, conceptions of beauty to the extent that they practice it. In the contemporary creation, certain elements are taken from popular art, without being mere copies or imitations, but giving them new content - "processing and framing as a whole a compositional structure, a creative manifestation of the elements of the plastic language" [6, p. 17].

In decorative art, the elements of nature are rendered in a simple form, obtained through stylization. This mode of play involves some creatively simplifying natural elements. Stylization represents the transformation of nature structures into plastic structures through geometry and abstracting, emphasizing their expressive particularities. The selection of the specific features of the represented reasons is the selection always accompanied by generalization 
(geometrized), creativity and plastic inventiveness. The essential character of the natural structures is preserved according to the working technique, the specificity of the textile art: painting on silk - batik, weaving (goblin, carpet), embroidery. The obtained by means of stylization plastic structures are called ornamental decorative motifs. Following the study of popular ornamentation, ornamental decorative motifs were classified into several large groups: abstract ornaments (geometric, freely drawn), cosmomorphic ornaments, phytomorphic (geometric) ornaments, zoomorphic ornaments (geometric), anthropomorphic ornaments, social ornaments (Figure 1) .

Fig. no. 1. Groups of decorative ornamental motifs

\begin{tabular}{|l|l|l|l|l|}
\hline $\begin{array}{l}\text { Abstract } \\
\text { ornaments }\end{array}$ & $\begin{array}{l}\text { Cosmomorphic } \\
\text { ornaments }\end{array}$ & $\begin{array}{l}\text { Phytomorphic } \\
\text { ornaments }\end{array}$ & $\begin{array}{l}\text { Zoomorphic } \\
\text { ornaments }\end{array}$ & $\begin{array}{l}\text { Anthropomorphic } \\
\text { ornaments }\end{array}$ \\
\hline$\because \because . \therefore$ & $\therefore$ &
\end{tabular}

- Abstract ornaments: geometric - point, several points, line, horizontal or vertical lines, overlapping lines; freely drawn - broken lines, curved lines, curled lines, intuitive lines; mixed - geometric and freely drawn shapes, geometric and nongeometric shapes.

- Cosmomorphic ornaments: geometrical - sun, sun and flower, stars, motif; freely drawn - stars, lightning, rainbow, corner bypassed with suns; mixed - sun in geometric transposition and freely drawn, astral motifs, composition with sun.

- Phytomorphic ornaments: geometric - flower, leaves, corn, tree of life, fir branches, flower-wheel; freely drawn - gorse leaf and a flower, chestnut leaf, acorn flower, acacia flower, flower and leaves; mixed - non-geometric and geometric floral composition.

- Zoomorphic ornaments, including avimorphs: geometrical - representations of horses, hawks, cocoons, butterflies, roosters, ram's horns; freely drawn - peacock, sheep, deer, pair of ox, bird, snail, rooster, wolf with sheep in mouth.

- Anthropomorphic ornaments: geometric and freely drawn - compositions with human faces.

- Social ornaments: geometric - peasant hour; freely drawn - the newlyweds, a 
round dance (hora); mixed - representations of peasants' (hora) round dance.

Ornamental decorative motifs are treated in two ways: synthetic and detailed. The geometrical ornaments, having at first a realistic motivation, symbolic through repeated processes of abstraction, have in time come to lose their initial meaning. The most common geometric ornaments in textile art are called in the popular language: the zigzag or the teeth of the saw, the apron or the rhombus, the squares (also called plates, pavers, ladies), the horns of the ram, the moss or the old lady etc. The geometry is characteristic for all categories of ornaments. Ornaments applied in textile art can be called abstract or generalized. The dots, the continuous lines, the dashed lines, the crosses, the squares, etc., even without having any emotional or ideational message, enhance the beauty of the decorative ornamental motifs applied in the creative textile compositions [2, $\mathrm{p}$. $18,19]$.

Therefore, the decorative ornamental motifs used for the elaboration of creative compositions cannot be applied without expressive expression. It is clear evidence that the methods of making the ornamental assembly were not accidental, but aimed at perfect harmony between the constituent parts. The mixed ornamental field, in which phytomorphic ornaments combine with zoomorphic and anthropomorphic ones, does not affect the compositional unit. In the case of Moldovan textile art, the compositional organization respects the two specific modalities of our popular art: the first - static, with an ordered, symmetrical arrangement, of the motifs according to ancient models, the second - dynamic, based on the element of surprise, betraying a tendency of decentralization [Ibidem, p. 38]. The mixed compositions, in which the geometrical element combines with phytomorphic, zoomorphic or anthropomorphic elements of the Moldovan folk ornament, are particularly original and convey a fresh sensation. Sometimes, in the center of the composition, a single tree appears, with branched branches, on which are different flowers, leaves and fruits. The frame is made up of geometrical or, rarely, plant (and often geometrical) motifs. Compositions with the surface sectioned into two or three rectangular registers can also be elaborated, which frame one tree and represent the compositional center of the creative work [2, p. 42]. In general, the geometry of plastic forms, as an efficient way of developing creativity, has worried many scholars in the field of art theory. In this context, W. Worringer mentions that form is represented by the art of ornamentation; this art is the expression of the relationship in which a community finds itself in front of the world; only after the syntax of the artistic language (the art of ornamentation) has been established can the human being translate the objects of the outer world into this language [Apud 5, p. 28]. Continuing this type of approach, L. Blaga notes the existence in the folk art of the Romanians of a geometrism of simple figurative essence, predominantly linear, static, less loaded, discreet, as well as the tendency to geometrize the motifs inspired by the surrounding nature [Apud 5, p. 29].

In his research on popular ornaments, Al. Dima notes some of their most 
important features: geometry in Romanian folk art; folk art uses the simplest geometric means. The author notes the process of associating motifs in ornamental compositions [Apud 5, p. 29]. I. Frunzetti has scientifically substantiated the realistic character of the geometrical ornamental motifs in the Romanian folk art: almost every geometrical motif is the result of the operation of adapting a realistic theme to the demands of the popular ornament; as a language, geometry can express realistic observation contents, yet geometry remains in formal relation. The author confirms that the geometry is specific to the Romanian folk decorative art which has the sensory, realistic, concrete meaning [Apud 5, p.30]. Therefore, the popular ornamentation (traditional and contemporary) consists of all the elements, motifs and ornamental compositions. The ornamental forms of folk art do not express a strictly individualized plastic creation, they are inserted in the ethnopsychological and ethnocultural context. Popular ornament expresses a specific phenomenon of communication, a message characterized by a language of a rare linear richness or free, rhythmic or arrhythmic forms, repetitive or alternating, symmetrical or asymmetrical. Ornamentation is a means of communication, like a code. The signs used in this code exceed the quality of simple graphic signs, becoming ornaments [5, p.61,62]. Based on the above, we find that the symbolism of the forms and its creative application in the plastic language offer vast possibilities for the development of creativity in the achievement of abstract decorative compositions at the university course in textile art. The study and analysis of the geometric symbol and the plastic symbol, but also the correlation between these symbols in the instructional process at the faculties of plastic art, is a basic condition in the process of elaborating creative plastic compositions.

The present study aims to analyze the correlation between the elements of the plastic language and the geometric forms for their conscious application in the elaboration of creative compositions, in the activity of creation of the future plastic artists. In the plastic arts, the organization of forms is an essential way of creation, art being conceived throughout the aesthetic development as a process of composition and elaboration. Viewed singularly, geometric shapes and figures can sometimes seem moving, and sometimes static. They can generate a set of sensations, of a certain quality when developing creative plastic geometric shapes and their conscious application in creating plastic compositions. Thus, the general language of geometric signs and symbols becomes a specific plastic language. The world of geometrical general notions enters the subjective world of the artist, who has the ability to combine these notions in the creative elaboration process of plastic compositions. The geometric and plastic combinations that underlie the artistic conception of a creative composition can be competed only by the possibility of expressing an infinity of thoughts, ideas, affective states with a limited number of geometric signs. The unanimously conventional language of geometry is the basis of an endless series of specific artistic languages. In addition, the geometric and plastic forms contain both semantic and syntactic 
characteristics. The unity and identity of the semantic and the syntactic comes from the fact that a certain sign, a certain geometric or plastic form contains both distinctive semantic and syntactic notes.

Among the conventional geometric codes it is considered that: the point corresponds to the idea of location, marking (punctuation); to the triangle corresponds, on the same plane of the psychology of perception, the idea of dynamism (a dynamism resulting from the force suggested vertically by the sharp tip of the angles, sometimes consecrated by the size and proportion of the closed figure); the square, due to the order within its area determined by the four right angles and the equality of the sides, corresponds to the notion of stability. The dictionary meaning explains the triangle as the first surface. Any geometric figure, if we take straight lines from its center to the corners, can be divided into several triangles. The triangle symbolizes divinity, harmony, proportion [3, p.382]. Derived from the structural geometrical and plastic condition of the triangle and the square, the expressivity follows: the sharp angle (below $90^{\circ}$ ), which assumes the dynamic vector condition mentioned in the case of the triangle, - pointing outwards; the obtuse angle (greater than $90^{\circ}$ ), which tends to lose its dynamic targeting capability of the suggested angle vector in favor of a force of opposite direction, pointing inwards at the opening of the angle arms; the situation is all the more clear as the obtuse angle is larger, approaching the condition of a circle arc or an open curve - pointing inwards. These geometric symbols are also applied in the elaboration of plastic compositions in textile art that use the visual image of the geometric symbol. The geometric sign appears frequently in simple, non-coded languages, or with an easily accessible number, without previous specialized training. Analyzing the principles of applying geometric symbols and shapes in the elaboration of decorative compositions, the process of transforming the geometric symbol into the plastic symbol is obvious and has as its purpose the synthesis (geometrical-plastic) of the signs that have become, through creation, symbols. The table below reflects the multitude of possibilities of expression of the line as an element of the plastic language in decorative composition, revealing all the characteristics and hypostases of the line in its closed and open version (Figure 2).

Fig. no. 2. Representation of line expression as an element of plastic language

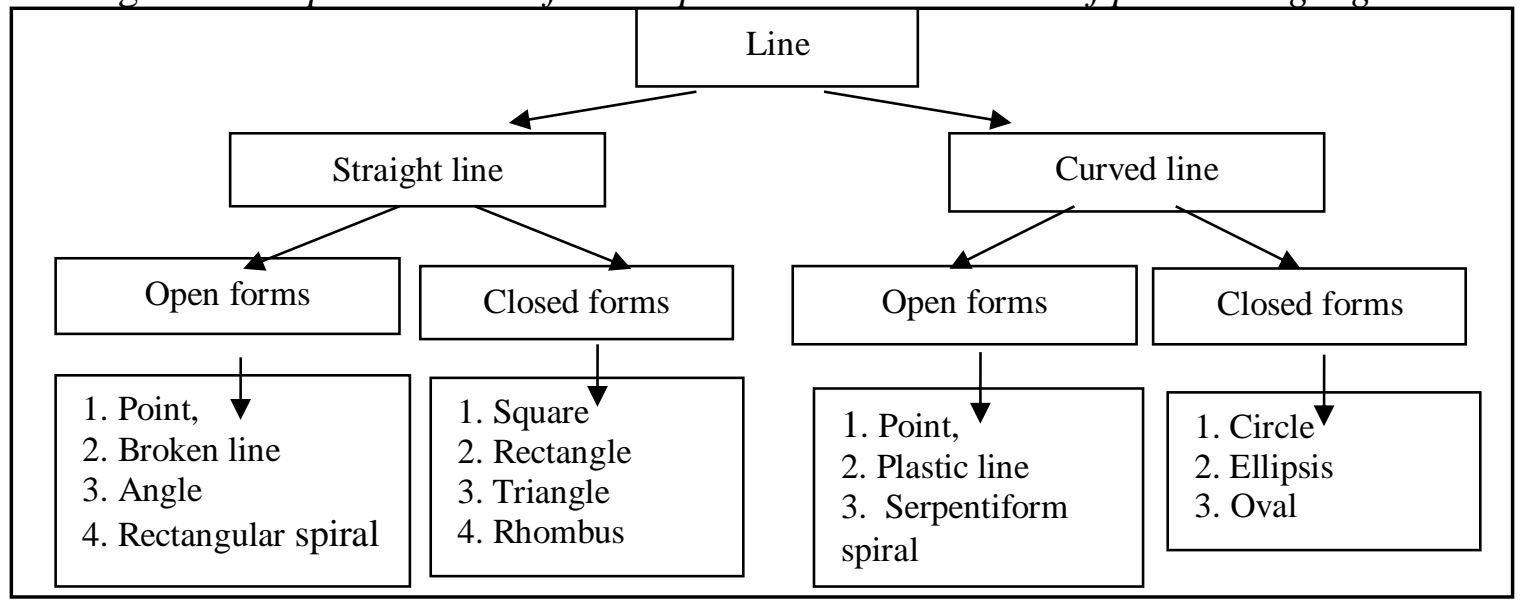


After many millennia, the primary signs became symbols, holy signs, and in the Christian era, with their abduction of the mythical spirit they took on an artistic model in plastic language. The geometric and plastic symbols emphasize the genetic trunk of people united by common beliefs and the perenniality of the signs that have linked bridges over time. Any creative process involves placing symbols in plastic language in a meaningful context. The symbols are in the center of attention, they are the heart of the imaginative life, because they reveal the secrets of the unconscious, they move the most hidden springs of actions and offer new perspectives on the unknown and the infinite. The symbol plays a dominant role, especially in textile art. In contemporary art and modern art, studying the symbol is also important for the successful creation of artistic creation in the field of textile art. The dictionary sense of the notion of symbol: symbol - sign, object, phenomenon, which is vested with a special capacity to convey ideas, even ideological allusions, which are much more complex than their simple representation, according to a generally accepted code. In the plastic arts, the symbol is a visual sign with an allusive character, referring to another material or spiritual reality, than the one that the image depicts, in the medieval art, of the Renaissance and the Baroque. The symbol can be noticed and intuitive, in some cases, when the sign and what it signifies have both a concrete character. However, there are also repertoire symbols of ancient visual experiences, such as color and numerical symbols [3 p.128].

We will examine the symbolic meanings of the elements of the plastic language, which are in correlation with the geometric shapes, specific and frequently applied in the elaboration of the plastic compositions in the field of textile art (spiral, angle, triangle, rhombus, cross, twin segments, circle). A sign with great power of influence in textile symbols, taken from the symbol and geometric form, is the spiral - that open curve line. Over the millennia, the spiral has taken different forms, with multiple meanings: repeated, opposite, clipped, fleeting, chain, veiled, braided, etc. The variants of the spiral identified in the national costume are, in fact, identical signs of the spiral that adorned the costume of the deities from Cârna, taken on a higher plane from much older local cultural glasses. The chain spiral, fleeing, in bound scrolls, known since the Neolithic in the area of the Danube Carpathians, was introduced in the ceremonial clothing complex.

The primary angle. In the practice of textile art, the angle has taken different faces, has been placed in different positions, according to some difficult to decipher requirements. Thus, the angles with the parallel sides bordered by two lines adorned the narrow collars, hemlines and borders of all types of clothing, using the black thread with predilection. The larger grouping of parallel angles, bounded by two lines, or not, with rib or not of the type of the one from Ostrovu Corbului or Parţa was used intensely, in the form of a cross, as a stand-alone element. The cross in little wings was an important source of ornament, being frequently associated with phytomorphic elements, which demonstrates that this 
motif was created later and derives from the bird-goddess pattern. In the textile ornament was maintained vigorously in the villages of Sibiu. With a square in the middle or not, this cross in ancient times was an important model in the embroidery of the garments in the villages of Briceni-Basarabia. Suliţa and Ostriţa-Bucovina remained preferable in sewing Moldovan towels [3, p.72].

The closed angle - the triangle "filled" or always outlined, has been an important source in the textile compositions in Muntenia and Country of Crisura. The angle formed by the frieze, created at Turk's Cuina and Turda, has spread in the clothing embroidery to a considerable extent because it is found on all the garments. Frequently it appears intercalated or repeated.

The rhombus on textile materials in the writing of the form was the sun's sign, and the Egyptians rendered it in tissue art, obtaining special reflexes and starting with the sixth millennium it was extended in all neolithic glass. The charged rhombus, whether circumscribed or suggested by the pairing of the hourglasses, has always created effect in composition through graphic simplicity and polychrome. Under the impulse of longtime forgotten traditions, it was often associated with the column, the angle and the parallel lines.

The twin segments. The multitude of pair- segments constituted a certain expression in the paleolithic language, subsequently confirmed in the windows of the Iron Gates area. The straight segments rendered in the bone, in the horn, in the clay, grouped the various kinds of worship accessories, either woven or embroidered. In those distant times, the group consisting of two segments represented the symbol of duality, the multiple, the group of three segments presented the image of the god of non-being, the group of four superlatively raised the dual multiple, etc., all pertaining to the structure of an archaic alphabet, later forgotten.

Alt semn primar - linia curbă închisă. Cercul, conturul mărgelei de la Nandru a luat chip diferit de-a lungul timpului scurs, ajungând în epoca bronzului un ax al fiinţei universale: Cultul Soarelui. La Spanţov-Olteniţa, cercul se haşura în interior, iar mai târziu se haşura numai spaţiul dintre două cercuri concetrice, aşa cum s-au brodat cojoacele în importantele centre de prelucrare a pieilor, cum se brodau cercuri pe colţul hainelor lungi în Bihor, Gorj, Dolj şi Romanaţi. Cercul $\mathrm{s}$-a asociat compoziţional cu spirala şi numai în cazuri rare a întrat în compoziţia frizelor alături de coloană, de unghi, sau de romb [3, p.73].

Another primary sign - the closed curve line. The circle, the contour of the bead from Nandru took a different face over time, reaching in the Bronze Age an axis of the universal being: the Cult of the Sun. In Spântov-Oltenita, the circle is hachured inside, and later only the space between two concentric circles is being hachured, as the coats were embroidered in the important centers of leather processing, as circles were embroidered on the corner of long clothes in Bihor, Gorj, Dolj and Romanians. The circle was compositionally associated with the spiral and only in rare cases entered the composition of the friezes next to the column, angle, or rhombus [3, p. 73]. 
Considered in particular, the geometric shapes and figures may appear moving or static, giving a set of sensations, of a particular quality when it comes to developing creative plastic geometric shapes and their conscious application in the elaboration of plastic compositions. The general language of geometric signs and symbols becomes a specific plastic language; the world of geometrical general notions is reduced to the subjective world of the artist, who has the ability to combine this data in the creative elaboration of plastic compositions. The geometric and plastic combinations, which are the basis of the (artistic) conception of a creative composition, can be competed only by the possibility of expressing an infinite number of thoughts, ideas, affective states with a small bunch of geometric signs. The unanimously conventional language of geometry is the basis of an endless series of specific artistic languages. The study of geometric symbols and plastic symbols and their application in the elaboration of creative compositions is an absolutely necessary condition in the process of developing artistic creativity in the students of the plastic arts faculties. We propose to develop the level of creativity in students through specific methods: the conscious study and application of plastic symbols, knowing all the particularities mentioned below. The study of plastic symbols will be carried out by:

- determining the semantic definition (plastic language elements, geometric shapes);

- analysis of symbols (elements of plastic language, geometric shapes);

- selection of symbols (elements of plastic language, geometric shapes);

- comparison (elements of plastic language, geometric shapes).

The conscious application of the symbolism of the plastic forms in the elaboration of creative compositions at the hours of textile art will suppose:

- the use of plastic language elements as plastic symbols;

- use of geometric shapes as geometric symbols;

- applying the philosophical concept of geometric symbols and plastic symbols in the elaboration of creative compositions;

- applying the psychological concept of geometric symbols and plastic symbols in the elaboration of creative compositions.

The development of creativity in students by studying and applying the symbolism of the plastic forms is a priority problem for the higher artistic education. The specific methods proposed foresee the initial stage in the elaboration of creative compositions for textile art activities. In the plastic arts, the application of symbolism is an essential process of creation, art being conceived throughout the ages as a means of aesthetic development and as a process of creation of the studious youth. The decorative structure of the popular ornament (traditional and contemporary) comprises: elements, motifs and ornamental compositions, which can be applied in the creation process in the students' works. The ornamental element constitutes the indivisible part, the simplest ornamental part, which can however appear by itself, in decoration (eg: 
a leaf, a petal, a branch, a stem, a fruit, etc.). The ornamental motif consists of two or more ornamental elements, making a whole decorative representation, divisible into ornamental elements of the same thematic group: flower (comprising leaves, petals etc.), large chariot (comprising more stars) etc. The ornamental composition results from two or more ornamental motifs, without necessarily being from the same thematic group, and not even from the same stylistic group: a bypass bypass (made in geometric style, comprising a chain of at least three broken lines, framed by a sequence of cuts); or a bypass with flowers (made in a non-geometric style, that is, in the form of a free drawing, and comprising a serpentine line, framed by a succession of phytomorphic and freely drawn motifs).

\section{Morphological classification}

A scientific systematization in traditional ornamentation should begin with the morphological classification of ornamental elements, motifs and compositions, and within it, with the liquidation of confusion between stylistic form and thematic content, between stylization type (form) and semantic classification (thematic or content of representations). From the point of view of the form or according to the type of stylization, that is, from the point of view of the morphological classification, three categories of ornaments are differentiated: on the one hand,

a) geometric and geometrical elements, motifs and ornamental compositions, rendered on axes or contours,

b) freely drawn - or non-geometrical, rendered mainly on the outlines; and on the other hand, a category derived from the first two, consisting of

c) mixed ornamental compositions, consisting of the combination of geometric and non-geometrical motifs (freely drawn) or of representations rendered in these two modes of treatment, but from different fields of inspiration. Considered as a whole, this category includes most of the abstract ornaments, a good part of the symbolic ones, as well as a part of the concrete, so-called realistic ones, in any case a large number of the old ornaments with an inspirational realistic topic, subjected over time to repeated operations of processing, generalization and abstraction.

An overview of the traditional Romanian ornamentation, from the point of view of its stylistic specificity, highlights the richness of the representations transposed into a geometric form. This mode of treatment, in fact with a universal spread, also known as elementary or elemental, leads, as L. Blaga points out, "to the excess the process of elimination and sees the need beyond what is generic, in some respects. elementary and universal things ". Through this stylistic process we reach forms" that completely exceed the organic, to contaminated forms as if by the geometric nature of the crystal patterns ". Whether they are transposed in a straight-line form, as in Romanian geometry, or in a dynamic rendering, as found in the ornamentation of the Nordic and Asian peoples (Chinese, Indians), the geometric decoration reflects only the essential lines of everyday beings and 
things.

The study of Romanian ornaments reveals that in traditional folk art the treatment of ornamental motifs is characterized by a straight-line geometry, by a simpler, more sober and more retained figurative invention, taking over and exploiting the traco-Dacian, Carpathian-Danube Carpathian-Danube geometric traditions. and southeastern European Byzantine [6, p.48, 49]. The process of abstracting in popular art usually means a shift from the perceived reasons at the beginning individually, from the surrounding reality, to the generalization of a mass of more or less similar reasons, the process continuing until the original meaning is omitted. The elements, motifs and compositions resulting at the end of this stylization process constitute the subdivision of ornaments that have become abstract. In contrast, some of the abstract ornaments are usually the result of the play of techniques and of following the natural suggestions of the materials to which they are applied.

As Nicolae Danăre mentions, from a stylistic point of view, abstract or abstract ornaments can be or can become geometrical, with freely drawn or mixed shapes. For example, the point and the line form the simplest and oldest ornamental elements in this category, common to the Romanian folk art, as to other peoples. The point bears various names (point, bud, points, drops, eyes, etc.), taken from the abstract or concrete ornamental theme. The line can be simple, or the result of joining several strokes, twigs or ages arranged parallel, in a transverse direction, when facing the structure of the material, or from overlapping lines, in warp and weft, on different popular textile pieces, in the specific transposed decoration. on textiles. [6, p.75].

The problems of geometry are discussed and debated in the first comments on Romanian folk art and, not infrequently, they have covered the whole theoretical field, talking about the preponderance or even the exclusivity of geometry in the vision of the popular artist. According to Ion Frunzetti, the geometry so prevalent in the foundations of folk art is only "the letter of the Romanian folk decorative art", the grammar of this language ", upon closer examination imposing the fact that the depth of this art, the spirit, its meaning is sympathetic, sensory, naturalistic, concrete ". The reduction, the synthesis process, the fixation of some geometrical structures, seem to us dictated by the need to put into circulation a certain mental operation, a logical discourse, a "writing" which, in its end, actually deepens the effort's implementation. general human cognitive in the immensity of the real, within the cultures in which the primitive mentalities are still active.

The filter of geometrical stylization, from the reduction of the image of an object to a few essential forms - equivalent to the angle, triangle, square, circle, rhombus etc. - in which the allusion to the configuration of reality is quite transparent, until the keeping of a sign that no longer constitutes an evocative call of the object, but only a purely conventional, symbolic reference, is applied for a large number of reasons. This process is also supported by the prominent 
representations of popular imagery - man, horse and rider, astral bodies, tree of life, etc., the multitude of motifs inspired by fauna and flora, the climate of daily life, or descending from the universe of fairy tales and mythology [8, p.31,34]. When studying the elements of plastic language and ornamental motifs in the educational methodology in the process of developing artistic creativity in students, the following aspects are considered:

- determining a group of elements of the plastic language and the plastic forms: point, line, square, rhombus, circle, etc .;

- investigation and knowledge of symbols and meanings in textile art through the elements of the studied plastic language: plastics, geometrical, ornamental;

- the correlation between the elements of the plastic language and the plastic, geometric, expressive, intuitive forms, the plastic structures.

To graph the above, we will use the form-content formula. We will notice that the forms specific to the plastic language contain information - contents (Figure 3).

Fig. no. 3. Methodology of studying plastic language

\begin{tabular}{|c|c|c|c|}
\hline \multicolumn{4}{|c|}{$\begin{array}{l}\text { Studying the elements of plastic language through the creative } \\
\text { application of the form-content formula }\end{array}$} \\
\hline 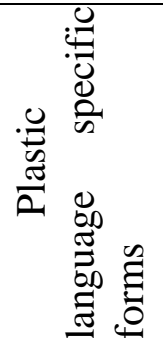 & $\begin{array}{l}\text { Plastic } \\
\text { Expressive } \\
\text { Freely drawn } \\
\text { Intuitive } \\
\text { Geometric } \\
\text { Ornamental } \\
\text { Traditional }\end{array}$ & 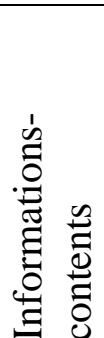 & $\begin{array}{l}\text { Symbolic } \\
\text { Semantic } \\
\text { Iconic } \\
\text { Conotative } \\
\text { Codified }\end{array}$ \\
\hline
\end{tabular}

The study of the plastic language by applying the form-content formula determines the specific forms of the plastic language and the information contents, in which, for the compartment, the specific forms of the plastic language are selected and presented in the following order: plastic, expressive, freely drawn, intuitive, geometric, traditional ornamental. The following types are specified for the Information-Contents compartment: symbolic, semantic, iconic, connotative, coded.

\section{Conclusions}

We mention that:

- developing artistic creativity by studying the elements of plastic language is a form of organization of the creative process;

- the process by which the young student is stimulated - the application of the elements of the plastic language in the creative process - optimizes and raises the aesthetic value of the creative works within the course of textile art. It is a necessary stage, prior to the intercommunication through the artistic language;

- the optimization of creativity maintains a high tone during the development of the creative process of studying and developing creative compositions with the conscious application of the plastic language in the creative works in the field of 
textile art;

- the plastic elements are the following: expressive expression, compositional laws, expressive organization of plastic language elements, artistic knowledge are constituted in plastic signs necessary for representations;

- from the perspective of the plastic language, the meaning of the creative product is given by the semantic-syntactic success, which includes an individual path in which each creative activity realizes the form - the content, the way in which the elements of the plastic language are superimposed, juxtaposed;

- the selection and processing of some elements of reality are operations (transformation, stylization, simplification) through elections and processing that illustrate an original way of rendering reality;

- the study of plastic language is a necessary stage, prior to the intercommunication through artistic language;

- practiced in various ways and working procedures, with various tools and materials, the language elements become creative affirmation tools for the creative personality. In this context, the development of creativity contributes to ensuring the autonomy of the creative personalities.

From the above, we can deduce that in the process of developing artistic creativity in students it is important to study the elements of plastic language by selecting and processing the elements in nature. Studying the elements of plastic language contributes to educating and informing the creative personality, at the same time choosing and processing reality in the context of a creative methodical thinking - together with the compositional laws, proportions, rhythm, movement, plastic forms.

The framework and reference objectives of the Textile Art course indicate the priority of the student's introduction in the theory of plastic language. It is essential to discover new possibilities for studying and applying the elements of plastic language in order to trigger students' creativity. To this end, in the course of textile art, we will examine the necessity of studying the plastic language, the synthesis of the creative forms in the context of the essential determination of the contents in the process of developing artistic creativity in the students.

\section{References}

1. Arbuz-Spatari O., Dezvoltarea creativității artistice la studenți în cadrul cursului de artă textilă: ghid metodologic/Arbuz-Spatari O., Simac A.: Chisinau, Garomond Studio, 2012. - 250 p.

2. Ciubotaru S., Ciubotaru I. Ornamente populare tradiţionale din Moldova (cusături, ţesături). Iasi: „Al. I.Cuza”University; Centre of linguistics, Literary History and Folklore, the Folklore Archive of Moldovei and Bucovina, 1988. 337 p.

3. Chevalier J. Gheerbrant A. Dicţionar de simboluri vol. I, II, III. Bucharest: Artemis, 1994. 503 p. 
4. Dicţionar de artă. Forme, tehnici, stiluri artistice. Vol. I, II. Bucharest: Meridiane, 1998. 188p.

5. Dumitrescu Z., Structuri geometrice structuri plastice. Buc: Meraresidiane 1984. $221 \mathrm{p}$.

6. Dunăre N. Ornamentica tradiţională comparată. Bucharest: Meridiane,1979. $159 \mathrm{p}$.

7. Mureşean D. Cunoaşterea şi creaţia artistică cu referiri speciale la artele plastice. Bucharest: Cybela, 2000. 110 p.

8. Prut C. Calea rătăcită. O privire asupra artei populare româneşti. Bucharest: Meridiane, 1991. $159 \mathrm{p}$.

9. Vasilescu V. Semnele cerului. Cultură şi civilizaţie carpatică. Iasi: ArhetipRenaşterea Spirituală, 1993. 214 p. 